\title{
Pengembangan aplikasi kesenian rengkong pada pembelajaran sastra berbasis kearifan lokal
}

\author{
D. Nurfajrin Ningsih ${ }^{a, 1^{*}}$, Aprilla Adawiyah ${ }^{b, 2}$, M. Irpan Abdurrohman Rozy ${ }^{c, 3}$ \\ a Pendidikan Bahasa dan Sastra Indonesia, FKIP, Universitas Suryakancana \\ b Pendidikan Bahasa dan Sastra Indonesia, FKIP, Universitas Suryakancana \\ c SMK Bela Nusantara Cianjur \\ Idinninurfajrin@gmail.com ${ }^{*}{ }^{2}$ aprilla.adawiyah@gmail.com ; ${ }^{3}$ rohmanrozy9@gmail.com \\ korespondensi penulis
}

\begin{tabular}{ll}
\hline Informasi artikel & \\
\hline Sejarah artikel: & \\
Diterima & 20 Juli 2019 \\
Revisi & 23 Agustus 2019 \\
Dipublikasikan & 30 Oktober 2019
\end{tabular}

Kata kunci:

Pengembangan

Aplikasi Kesenian Rengkong

Nilai Karakter

\begin{abstract}
ABSTRAK
Penelitian ini bertujuan untuk mendeskripsikan pengembangan aplikasi kesenian Rengkong serta pemanfaatannya dalam pembelajaran sastra berbasis kearifan lokal. Metode dalam penelitian ini adalah penelitian dan pengembangan (research and development) untuk menghasilkan produk sekaligus menguji keefektifan produk tersebut. Pengembangan aplikasi berbasis mobil dibuat menggunakan software Android Studio. Setelah proses pembuatan aplikasi selesai, dilakukan proses testing dan mempublish ke format apk yang dapat diunduh melalui pasar aplikasi yaitu Google Play Store dan dapat dijalankan di smartphone berbasis Android. Adapun hasil validasi dan penerapan aplikasi kesenian Rengkong pada pembelajaran yakni sebagai berikut I) Hasil validasi ahli pengembangan aplikasi kesenian Rengkong dalam pembelajaran sastra berbasis kearifan lokal masuk dalam kategori cukup untuk dijadikan bahan pembelajaran. 2) Hasil angket penerapan pembelajaran menulis puisi pada siswa SMK Negeri I Cianjur dengan jumlah responden 33 orang, diperoleh presentase sebanyak $74 \%$. Artinya penggunaan aplikasi kesenian rengkong dalam pembelajaran sastra berbasis kearifan lokal tersebut dapat digunakan dalam pembelajaran karena sudah masuk dalam kategori cukup. 3) Nilai-nilai pendidikan karakter pada puisi siswa terdiri dari: lima nilai menghargai prestasi, dua nilai cinta tanah air, empat belas nilai religius, enam nilai jujur, tiga nilai kerja keras, enam nilai tanggung jawab, empat nilai toleransi, dan tujuh nilai kreatif
\end{abstract}

Key word:

Development,

Rengkong Art Application,

Character Values

\begin{abstract}
The objective of this research was to describe the development of Rengkong art application and its utilization in the learning of literature based on local wisdom. The research employed research and development method. This method was used to produce products and test the effectiveness of these products. Development of mobile-based learning media applications created using Android Studio software. After the application creation process was complete, afterward the testing process and publishing to apk format were carried out to make it available in the application market, namely the Google Play Store and could be operated on Android-based smartphones. Based on the results of the validation and implementation of the Rengkong application in learning, the following results were obtained: I) The validation results of Rengkong application development in local wisdom-based literature learning fell into the category of sufficient to be used as learning material. 2) The results of the questionnaire of writing poetry learning towards the students of SMK Negeri I Cianjur with 33 respondents, obtained a percentage of $74 \%$. It means that the use of Rengkong application in literature learning based on local wisdom could be used in learning because it was included in the sufficient category. 3) The values of character education in students' poems consist of: five values of appreciating achievement, two values of the love of the motherland, fourteen religious values, six values of honesty, three. values of hard work, six values of responsibility, four values of tolerance, and seven values of creativity
\end{abstract}

Copyright (C) 2018 Universitas Ahmad Dahlan. All Right Reserved 


\section{Pendahuluan}

Warisan budaya dapat diartikan sebagai produk atau hasil budaya fisik dari tradisi-tradisi yang berbeda dan prestasi-prestasi spiritual dalam bentuk nilai dari masa lalu yang menjadi elemen pokok dalam jati diri suatu kelompok atau bangsa. Sehingga dapat disimpulkan, warisan budaya merupakan hasil budaya baik dalam bentuk fisik (tangible) maupun non-fisik (intangible) dari masa lalu.

Beragam wujud warisan kebudayaan memberi kesempatan kepada masyarakat untuk mempelajari kearifan lokal dalam mengatasi masalahmasalah yang dihadapi di masa lalu untuk kemudian dilihat relevansinya dengan masa sekarang (Davison, I99I). Namun, kearifan lokal seringkali diabaikan dengan alasan tidak ada relevansi dengan masa sekarang. Dampaknya adalah banyak warisan budaya yang lapuk dimakan usia, terlantar, terabaikan, bahkan dilecehkan keberadaannya (Karmadi, 2007). Pendidikan merupakan upaya sadar manusia dalam memahami diri sendiri dan lingkungannya. Dewasa ini banyak sekali fenomena yang merusak moral masyarakat terutama pelajar. Adanya arus globalisasi yang tidak terbendung semakin mewarnai sistem kehidupan sosial masyarakat maupun budaya dalam masyarakat di Indonesia. Hal tersebut terlihat dengan maraknya pergaulan bebas, kasus narkotika, kekerasan, dan minum minuman keras (Setyowati, 2009).

Di tengah arus tersebut peserta didik semakin tidak peka dan tidak mengetahui tentang sejarah dan kearifan lokal yang ada dalam masyarakat. Pendidikan di Indonesia membutuhkan pendidikan yang dapat membentuk karakter peserta didik sesuai dengan karakter yang terdapat dalam kearifan lokal. Sebagai contoh kesenian Rengkong dari Cianjur yang kaya akan pendidikan karakter. Jika dipahami dengan seksama kesenian tersebut mengajarkan hubungan kita dengan tuhan, hubungan manusia dengan manusia, dan hubungan manusia dengan alam. Pendidikan karakter tersebut akan membentuk kepribadian peserta didik dan melahirkan peserta didik yang bermoral. Solusi yang ditawarkan dalam penelitian ini adalah mengembangkan pembelajaran sastra berbasis kearifan lokal dengan menggunakan aplikasi yang memperkenalkan kesenian rengkong, dengan memuat foto-foto, video, sejarah, dan perlengkapan yang digunakan dalam kesenian tersebut.

Pengembangan aplikasi banyak dikembangkan pada abad ke-2I. Aplikasi yang sudah terancang dengan baik ini digunakan untuk mempermudah penyelesaian pekerjaan sehingga beban kinerja manusia bisa terkurangi. Salah satu jenis aplikasi yang dikembangkan yaitu aplikasi multimedia. Pembuatan aplikasi multimedia merupakan salah satu alternatif dalam menyelesaikan masalah tersebut. Multimedia berasal dari teater, yaitu pertunjukan yang memanfaatkan lebih dari satu medium di panggung yang mencakup monitor video, synthesized band, dan karya seni manusia sebagai bagian dari pertunjukan. Pengertian kedua mensyaratkan adanya sinkronisasi berbagai media tadi dengan bantuan komputer, membedakkan dengan pengertian multimedia yang pertama yang memanfaatkan berbagai media yang terpisah dan berdiri sendiri (Hamalik, 2005). Unsur-Unsur multimedia (Haryadi, 2006) meliputi:

a. Gambar

Gambar dapat meringkas dan menyajikan data kompleks dengan cara yang baru dan lebih berguna. Gambar sering kali muncul sebagai backdrop (latar belakang) yang mempermanis teks.

b. Audio

Multimedia tanpa bunyi hanya disebut unimedia, bukan multimedia. Masing-masing kemampuan membutuhkan teknologi, perangkat keras, dan perangkat lunak untuk menjalankannya. Ada tiga belas jenis objek bunyi yang bisa digunakan dalam produksi multimedia, yakni format waveform audio, aiff dat, ibf, mod, rni, sbi, snd, voc, au, MIDI soundtrack, compact disk audio, dan MP3 file.

\section{c. Video}

Video menyediakan sumber daya yang kaya dan hidup bagi aplikasi multimedia. Ada empat macam video yang dapat digunakan sebagai objek link dalam aplikasi multimedia : live video feeds, videotape, videodisc, dan digital video.

d. Animasi

Dalam multimedia, animasi merupakan penggunaan komputer untuk menciptakan gerak pada layar. Animasi terbagi menjadi sembilan macam yaitu animasi sel, animasi frame, animasi sprite, animasi lintasan, animasi splin, animasi vector, animasi karakter, animasi computational, dan morphing.

Pengembangan aplikasi multimedia tersebut dapat menunjang proses pembelajaran. Pembelajaran merupakan suatu proses belajar mengajar yang lazimnya terjadi di ruang kelas baik di sekolah, kampus maupun lembaga lain seperti tempat kursus ataupun private. Pembelajaran konvensional yang menggunakan satuan kredit semester atau jam pelajaran ditambah jika mata pelajaran tersebut memiliki banyak materi yang harus dibahas, tentu akan menyita banyak waktu. Diperlukan satu solusi berupa waktu tambahan belajar selain belajar interaktif di kelas. Salah satunya dengan menggunakan aplikasi pembelajaran (Bakti, Hasibuan, Sianturi, \& Sianturi, 2016). 
Kini aplikasi pembelajaran mudah didapatkan dengan menggunakan smartphone. Smartphone adalah perangkat telepon genggam yang bisa digunakan untuk berkomunikasi (mengirim pesan singkat dan telepon). Di dalamnya terdapat fungsi PDA (Personal Digital Assistant) yang dirancang untuk mengatur penyimpanan data, nomor telepon, agenda, dll. Menurut lembaga riset Roy Morgan, pada tahun 2012-2013 kepemilikan smartphone di Indonesia naik dua kali lipat, yaitu dari $12 \%$ menjadi $24 \%$ dari total populasi di Indonesia. Kepemilikan smartphone tersebut didominasi oleh remaja, dari total kepemilikan smartphone, 89\% menggunakan smartphone mereka untuk berinteraksi dengan teman-teman, kemudian $56 \%$ menggunakan smartphone mereka untuk berinteraksi dengan keluarga mereka, dan 35\% lainya menggunakan smartphone mereka untuk berkomunikasi dengan guru-guru mereka. Menurut lembaga riset Digital Marketing Emarketer jumlah pengguna aktif smartphone di Indonesia pada tahun 2018 akan mencapai lebih dari 100 juta orang (Setiadi, Yuliatmojo, \& Nurhidayat, 2018).

Penelitian ini sejalan dengan penelitian yang berjudul Pengembangan Aplikasi Multimedia Pembelajaran Interaktif Untuk Mata Pelajaran Bahasa Indonesia oleh Syamsiah Program Studi Informatika, Universitas Indraprasta PGRI tahun 2017. Tujuan penelitian ini adalah membuat aplikasi pembelajaran Bahasa Indonesia Interaktif berbasis multimedia sebagai alternatif media pembelajaran yang mudah dipelajari dan dipahami oleh siswa dengan konsep edutainment pada Bimbel D-LLA COURSE. Aplikasi ini dibuat dengan menggunakan software Macromedia Flash (Syamsiah, 2017). Kedua penelitian ini sama-sama membuat aplikasi pembelajaran.

Aplikasi Kesenian Rengkong yang dapat diakses dengan smartphone melalui play store dibuat untuk memperkenalkan seni Rengkong yang hampir punah. Kesenian tersebut diciptakan pada saat pesta panen tahun 1965 oleh Bapak Said (Almarhum) di Cianjur tepatnya di Kampung Kandangsapi Rt OI/ Rw 06, Desa Cisarandi, Kecamatan Warungkondang, Kabupaten Cianjur. Rengkong berfungsi sebagai media hiburan saat mengangkut padi dari sawah. Kemudian kesenian rengkong dikembangkan dan mulai dipentaskan pada tahun 1967. Bapak Suhanda yang merupakan keturunan alm. Bapak Said yang kini meneruskan kesenian Rengkong. Beliau mengungkapkan bahwa kesenian Rengkong sarat akan simbol-simbol. Alat dan bahan yang digunakan untuk bermain kesenian rengkong yaitu bambu kering (awi gombong) berukuran 2 - 2.5 meter, sunduk, tali ijuk, padi, pohon beringin, pohon hanjuang, bendera merah putih, umbul-umbul. Sedangkan kostum pakaian yang dipakai adalah baju dan celana pangsi hitam, ikat kepala, topi (cetok, dudukuy), sarung, sendal karet hitam, dan tidak diperbolehkan sendal berwarna merah karena itu salah satu warna bendera Indonesia (Ningsih \& Erdlanda, 2018).

Aplikasi pembelajaran kesenian Rengkong dibuat untuk menumbuhkan nilai karakter siswa. Pendidikan karakter merupakan konsep pendidikan integratif yang tumpuannya tidak hanya pada pengembangan kompetensi kognitif semata, tetapi juga pada penanaman nilai etika, moral dan spiritualnya (Rabiah, 2018). Upaya yang dapat dilakukan dalam penguatan karakter adalah menginternalisasi nilai kearifan lokal pada pembelajaran. Kearifan lokal adalah hasil gagasan atau pandangan hidup dan ilmu pengetahuan yang berasal dari pengalaman suatu masyarakat maupun kebiasaan berwujud yang dilakukan oleh masyarakat lokal (Fajarini, 20I4). Budaya dan tradisi merupakan kekayaan beragam dari bangsa Indonesia yang terlahir juga dari beragamnya suku bangsa. Keragaman budaya yang dimiliki harus dihargai, diapresiasi, dan dijunjung oleh bangsa Indonesia, karena budaya dapat menjadi jati diri bangsa dan karakter atau ciri khas suatu bangsa (Adawiyah \& Munsi, 2018).

Berdasarkan penjelasan di atas maka pengembangan aplikasi kesenian Rengkong pada pembelajaran sastra, diharapkan dapat meningkatkan kecintaan terhadap kearifan lokal dan dapat membentuk karakter siswa.

\section{Metode}

Metode dalam penelitian ini adalah metode penelitian dan pengembangan (research and development). Menurut Sugiyono, metode pengembangan digunakan untuk menghasilkan produk tertentu dan menguji keefektifan produk tersebut (Sugiyono, 2010). Metode pengembangan merupakan hasil adaptasi dari model pengembangan ADDIE yang dikembangkan oleh Dick and Carry (I996) dalam (Setiadi et al., 2018) untuk merancang media pembelajaran. Model pengembangan terdiri dari lima tahap yang meliputi:

I. Analisis (analysis),

Pada tahap analisis ini penulis mendapatkan informasi dari hasil wawancara dengan penggiat seni Rengkong. Kesenian ini sudah jarang ditampilkan sehingga masyarakat kurang mengenal kesenian ini. Oleh karena itu, pemanfaatan aplikasi kesenian Rengkong sangat penting dalam merevitalisasi kearifan lokal.

\section{Desain (design),}

Desain produk yang dibuat berupa prototype yang kemudian dikembangkan menjadi aplikasi pembelajaran kesenian rengkong. Rancangan untuk 
aplikasi ini dibuat dengan menampilkan konten beranda yang berisi, sejarah, peralatan, pemeran, dan pementasan, selain itu ada tampilan untuk galeri foto dan video,

3. Pengembangan (development),

Pada tahap pengembangan awal aplikasi tersebut di validasi oleh ahli media dan diuji cobakan pada kelompok terbatas.

4. Implementasi (implementation),

Setelah aplikasi tersebut di validasi dan diujikan pada kelompok terbatas, selanjutnya tahap implementasi pada pembelajaran sastra (menulis puisi) dengan aplikasi kesenian Rengkong.

5. Evaluasi (evaluation)

Pada tahapan ini dilakukan evaluasi hasil penerapan aplikasi kesenian Rengkong pada pembelajran sastra.

Penelitian ini dilakukan pada siswa kelas XTKJ-I SMK Negeri I Cianjur yang beralamat di J1. Siliwangi no 4I Sawah Gede kecamatan Cianjur Jawa Barat.

\section{Hasil dan pembahasan}

\section{Kearifan Lokal dan Nilai-nilai Karakter dalam Kesenian Rengkong}

Hasil wawancara dan pertunjukan yang dilakukan oleh para seniman Rengkong, dapat diperoleh data yang mendeskripsikan nilai kearifan lokal dan nilai karakter dalam kesenian tersebut. Seperti yang dijelaskan oleh Suhanda (pewaris, 52 tahun) terdapat beberapa alat dan bahan yang digunakan dalam pertunjukan Rengkong yang sarat makna. Begitu pun saat melakukan pergelaran atau pertunjukannya. Makna-makna yang muncul berkaitan erat dengan kearifan lokal dan nilai karakter. Fajarini (20I4) berpendapat bahwa kearifan lokal adalah hasil dari masyarakat tertentu melalui pengalaman yang belum tentu dialami masyarakat yang lain. Kearifan lokal juga dapat diartikan sebagai pandangan hidup dan ilmu pengetahuan juga berbagai strategi kehidupan yang berwujud dilakukan oleh masyarakat lokal. Terdapat beberapa ciri kearifan lokal, yaitu (I) berdasarkan pengalaman, (2) teruji setelah digunakan berabad-abad, (3) dapat diadaptasi dengan kultur kini, (4) padu dalam praktik keseharian masyarakat dan lembaga, (5) lazim dilakukan oleh individu masyarakat dan lembaga, (6) bersifat dinamis dan terus berubah, dan (7) sangat terkait dengan sistem kepercayaan (Alwasilah, et al dalam Danial \& Prayogi, 2016). Berdasarkan hal tersebut dapat dipahami bahwa kearifan lokal dapat menjadi identitas atau jati diri suatu kelompok etnis atau komunitas tertentu. Sama halnya dengan kesenian Rengkong yang memiliki nilai kearifan lokal dalam beberapa bahan/alat dan saat pertunjukan, yang dideskripsikan sebagai berikut. a) Berdasarkan Pengalaman

Dari hasil wawancara, dikatakan oleh Suhanda (52 tahun, pewaris kesenian Rengkong), kesenian Rengkong diciptakan pada saat pesta panen tahun 1965 di Cianjur, Kampung Kandangsapi Rt. 0I/Rw. 06, Desa Cisarandi, Kecamatan Warungkondang oleh Bapak Said (Almarhunm). Tujuan diciptakannya sebagai hiburan saat pulang dari panen. Kesenian Rengkong ini sebenarnya bukan hanya terdapat $\mathrm{di}$ Cianjur, tetapi juga di Sumedang dan Banten. Terdapat hal yang membedakan antara kesenian Rengkong Cianjur dengan kesenian Rengkong daerah tersebut, yaitu jumlah berat beban pikulan padi yang hanya 2 ikat ( 2 gedeng) dengan rincian I ikat di depan dan I ikat di belakang dengan jumlah total 20-25 kg. Berbeda halnya dengan daerah lain yang berjumlah 4 ikat dengan total $40 \mathrm{~kg}$. Penamaan Rengkong berdasarkan pada kemiripan suara dengan salah satu jenis burung besar berwarna hitam pekat dengan paruh besar, yaitu Rangkong/Rengkong/Enggang. Pada pelaksanaan/pertunjukannya, dipertunjukkan oleh pemain Rengkong berjumlah 6 orang yang kemudian dikembangkan menjadi I8 pemain.

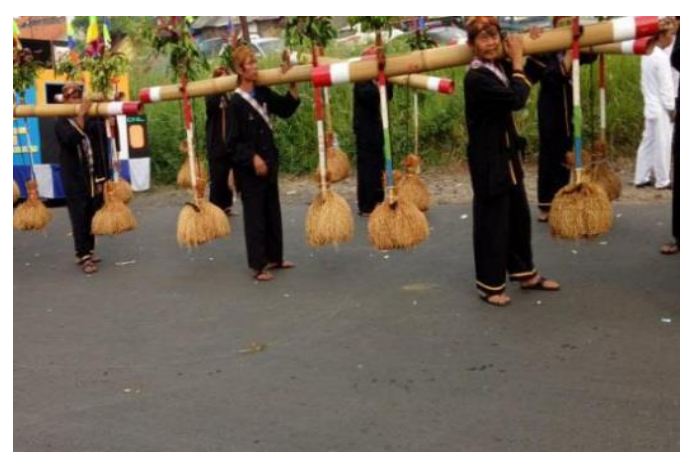

Gambar I. Pemain Rengkong memukul bambu dengan padi

b) Teruji setelah digunakan berabad-abad

Kesenian Rengkong diciptakan pada tahun I965 dan saat ini telah memasuki generasi kedua. Padi yang digunakan pada kesenian Rengkong merupakan padi besar (huma) dan padi Pandan Wangi yang mampu bertahan sampai 20 tahun. Sejak dahulu kesenian ini sering dipentaskan dalam berbagai acara dan di berbagai daerah, seperti peringatan hari kemerdekaan, hari ulang tahun daerah, acara sekolah, acara hajatan, acara pentas budaya. Biasanya ditampilkan di desa, kecamatan, kabupaten, hingga skala nasional.

c) Dapat diadaptasi dengan kultur kini

Kesenian Rengkong sangat mempertahankan beberapa warisan yang telah diciptakan oleh pendirinya terdahulu. Seperti, alat dan bahan yang digunakan haruslah sama (bambu haruslah bambu 
Gomobong, padi yang digunakan harus padi besar atau pandan wangi, ikatan padi, sunduk, warna pada bambu dan sunduk, beringin, daun hanjuang, dan sebagainya), para pemain yang menggunakan pangsi warna hitam, gerakan memikul padi, dan suara yang harus dihasilkan dalam pertunjukan Rengkong. Kesenian ini merupakan kesenian yang hanya menghasilkan gerakan dan suara (yang dihasilkan dari pikulan bambu). Selain mempertahankan warisan, seni Rengkong juga dapat diadaptasi dengan budaya kini. Meskipun kemunculan kesenian Rengkong tidak dipengaruhi oleh kesenian lain, seiring perkembangan zaman, kini kesenian ini sering dikolaborasikan dengan kesenian lain, terutama seni tari. Biasanya divariasikan dengan tari potong padi (berasal dari tempat yang sama) yang dibawakan oleh kaum ibu atau dengan tari Dewi Sri ngacleuk leuit (dari Ciranjang) di bawah pipiman ketua Dinas Kebudayaan Cianjur.

d) Padu dalam praktik keseharian masyarakat dan lembaga

Rengkong dilakukan oleh masyarakat dengan tujuan sebagai hiburan ketika panen. Hal ini menunjukkan bahwa masyarakat Cianjur pada umumnya bermata pencaharian sebagai petani. Seperti yang tergambar pada satu di antara 7 pilar budaya Cianjur, yaitu tatanen (pertanian). Sehingga, dapat dikatakan bahwa kesenian Rengkong tercipta dan dipertunjukkan selaras atau padu dengan praktik keseharian masyarakat yang bertani, bergotong royong, dan bekerja sama juga padu dengan program dari Cianjur dan dinas kebudayaan Cianjur.

e) Lazim dilakukan oleh individu masyarakat dan lembaga

Kesenian Rengkong dimainkan oleh enam orang (sesuai dengan rukun iman), kemudian berkembang menjadi I8 anggota pemain dengan satu orang ketua. Para pemain kesenian Rengkong tersebut merupakan kelompok masyarakat di desa Cisarandi dengan ketua yang merupakan pewaris kesenian Rengkong. Dinas Kebudayaan Cianjur juga ikut serta dalam pelestarian kesenian tersebut.

f) Bersifat dinamis dan berubah

Seperti yang dijelaskan sebelumnya, kesenian Rengkong merupakan seni yang dinamis dan berubah (tanpa mengurangi esensi/makna setiap gerakan, alat, dan bahan). Misalnya, terdapat perubahan dari 6 pemain menjadi 18 pemain, dapat diiringi tari potong padi atau sejenisnya. Kesenian Rengkong dapat berkembang seiring perkembangan zaman akan tetapi tetap mempertahankan keasliannya.

g) Sangat terkait dengan sistem kepercayaan

Penciptaan seni Rengkong didasari pada rasa syukur atas hasil panen yang melimpah. Dari penjelasan Bapak Suhanda, bahwa sebelum pelaksanaan seni Rengkong biasanya dilakukan doa dan shalawat bersama, menandakan adanya kepercayaan pada Allah SWT. Hal ini juga terlihat pada penggunaan alat dan bahan, seperti bambu (awi gombong) yang dipilih harus lurus yang menandakan bahwa setiap manusia harus patuh pada jalan sang Maha Pencipta; pohon hanjuang yang menjadi ciri batasan yang baik dan benar; tali ijuk sejumlah tiga ikat yang menandakan antara ucapan, langkah, dan tekad harus satu ikatan dan bermanfaat untuk dunia dan akhirat. Selain itu, terdapat juga kepercayaan zaman dahulu mengenai adanya dewi padi (Dewi Sri) yang menjaga kesuburan tanah dan padi, ditandai dengan adanya leuit (tempat penyimpanan padi) yang dijadikan tanda tempat lumbung padi khas Sunda juga sebagai kehadiran Dewi Sri.

Gambar 2. Leuit atau lumbung tempat penyimpanan padi

I) Nilai Pendidikan Karakter Di samping memiliki kearifan lokal,

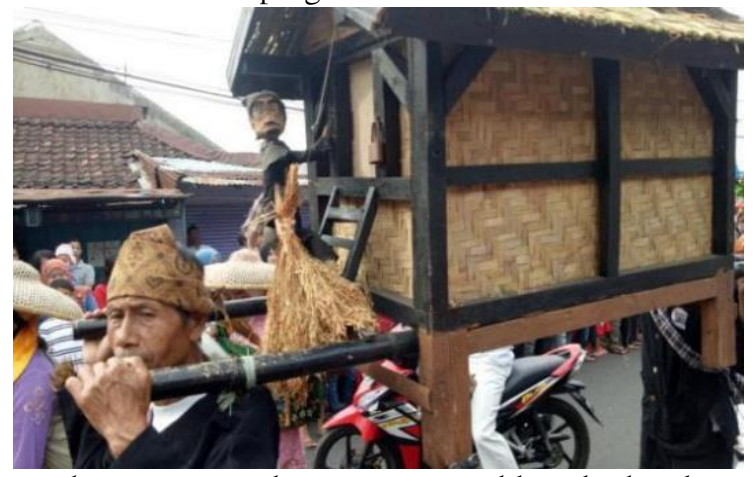

kesenian Rengkong juga memiliki nilai karakter pada setiap gerakan, pertunjukan, alat dan bahannya. Sejalan dengan penelitian (Ningsih, Adawiyah, \& Munsi, 2019) dari I8 nilai karakter, hanya terdapat I3 nilai karakter dalam kesenian Rengkong, yang dipaparkan sebagai berikut.

a) Religius : ditandai dengan pemilihan bambu yang memiliki makna lurus ke atas, beriman hanya pada Allah; jumlah pemain dan bambu (pada zaman dulu) sebanyak 6 buah, menandakan rukun iman; tali ijuk yang menandakan mengikat agar dunia dan akhirat selaras; pemilihan pohon hanjuang, yang dapat mengartikan adanya pilihan yang baik dan yang benar, untuk pembeda atau pembatas antara yang baik dan yang benar, yang halal dan yang haram; dalam pelaksanaan rengkong syukuran kepada Allah, berdoa dan bershalawat.; bambu

a) menjadi pegangan agama; suara harus memiliki makna baik dunia maupun akhirat.

b) Jujur: jumlah tali ijuk (3 buah) yang bermakan bahwa tekad, ucapan, dan langkah harus selaras; sunduk yang berdiri di atas bambu bermakna 
harus menjadi tegak dan benar dalam menjalani kehidupan (ajeg, panceg walau kesulitan).

c) Disiplin: mengikuti aturan, baik dari bahan, jumlah tali ijuk, padi yang digunakan (pare huma dan pandan wangi yang berusia 20 tahun; I5 kilo untuk beratnya minimal), gerakan masih sama dengan yang diajarkan.

d) Kreatif: mengembangkan dan meneruskan rengkong tanpa diajarkan terlebih dahulu (dari formasi 6 orang menjadi I4 orang), membuat lubang pada bambu dan memberikan minyak agar menghasilkan suara.

e) Kerja keras: upaya melestarikan kesenian rengkong; bahan-bahan yang harus bahan tertentu menunjukkan adanya kerja keras dalam pembuatan.

f) Mandiri: mempelajari secara mandiri kesenian rengkong/tidak diajarkan.

g) Semangat kebangsaan: warna di sunduk dan bambu yang berwarna merah putih, harus utuh karena menggambarkan bendera merah putih.

h) Cinta tanah air: warna merah putih pada bambu dan sunduk harus utuh karena lambang negara tidak bisa diganggu. Pada umbul-umbul terdapat bendera merah putih, gerakan-gerakan umbulumbul sehigga merah putih berikibar.

i) Menghargai prestasi: menghargai hasil karya leluhur atau orang-orang terdahulu, menghargai keberhasilan petani dalam panen, umbul-umbul yang bergerak, mengibarkan bendera merah puitih mengingatkan perjuangan pahlawan.

j) Toleransi: pohon beringin yang mengayomi.

k) Peduli lingkungan : bersyukur akan hasil panen/padi.

1) Peduli sosial: beringin bermakna melindungi dan mengayomi.

m) Tanggung jawab: tanggung jawab memikul beban, melestarikan rengkong.

\section{Hasil Pengembangan Produk Aplikasi Berbasis Mobile}

I) Pembuatan Aplikasi

Tahap pembuatan aplikasi merupakan tahap realisasi dari perancangan flowchart dan design interface, pada tahap ini aplikasi media pembelajaran berbasis mobile dibuat dengan menggunakan software Android Studio. Gambar 2 adalah antarmuka pengguna Android Studio.

$$
\text { Langkah-langkah pembuatan aplikasi }
$$
dengan menggunakan software Android Studio :

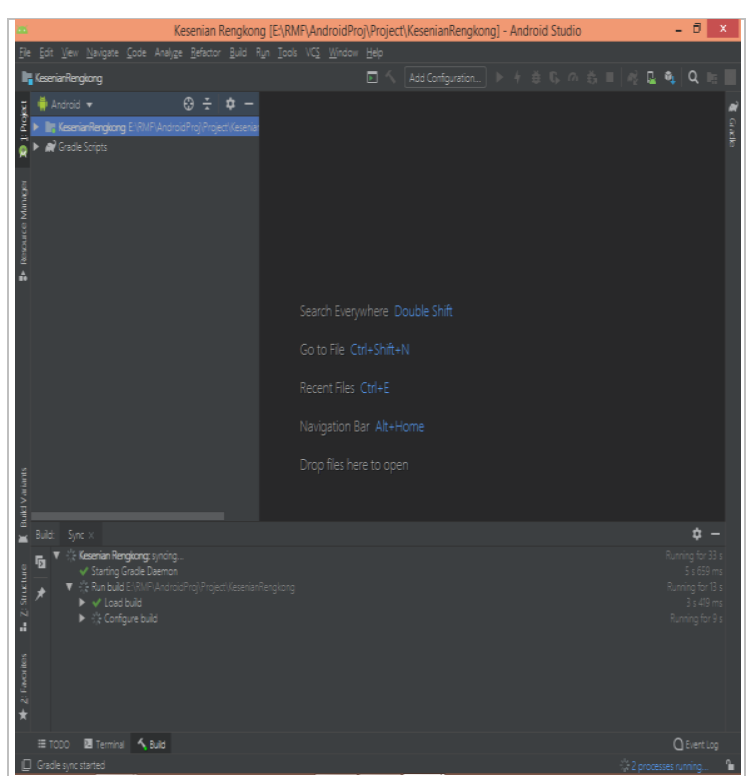

\section{Gambar I Antarmuka Android Studio}

langkah awal yaitu dengan membuat projek baru klik pada File lalu klik $N e w$ dan pilih $N e w$ Project, kemudian pilih project Phone and Tablet dan memberi nama project sekaligus memilih minimal compactibility Android OS version sebagai pembatas penggunaan pada sistem operasi Android versi tertentu. Mulailah mendesain tampilan aplikasi sesuai dengan konsep peracangan yang telah dibuat sebelumnya. Android Studio memberikan pengalaman terbaik untuk mendesain tampilan aplikasi dengan menggunakan fitur Drag and Drop, yaitu cukup menggeser komponen kemudian meletakkan sesuai rancangan antarmuka yang telah dibuat. Gambar 3 menunjukkan tampilan pembuatan konten aplikasi kesenian rengkong.

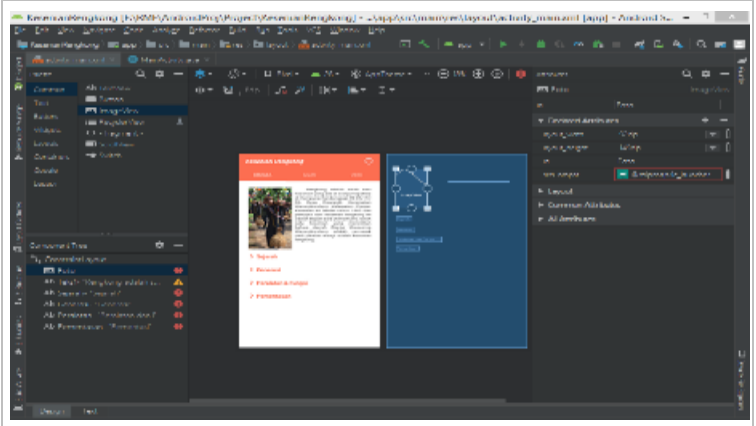

Gambar 2. Pembuatan Konten Aplikasi

Pada setiap antarmuka memiliki kode sumber yang berfungsi untuk menampilkan sub-sub teks yang dihide and show, memperbesar gambar yang dipilih, memutar video dan perpindahan dari antarmuka ke antarmuka lainnya dengan motion swipe horizontal atau mengklik tab menu. Kode sumber yang 
digunakan dalam Android Studio ini yaitu bahasa pemrograman Java. Gambar 4 menunjukkan tampilan kode sumber/syntax java pada pembuatan aplikasi.

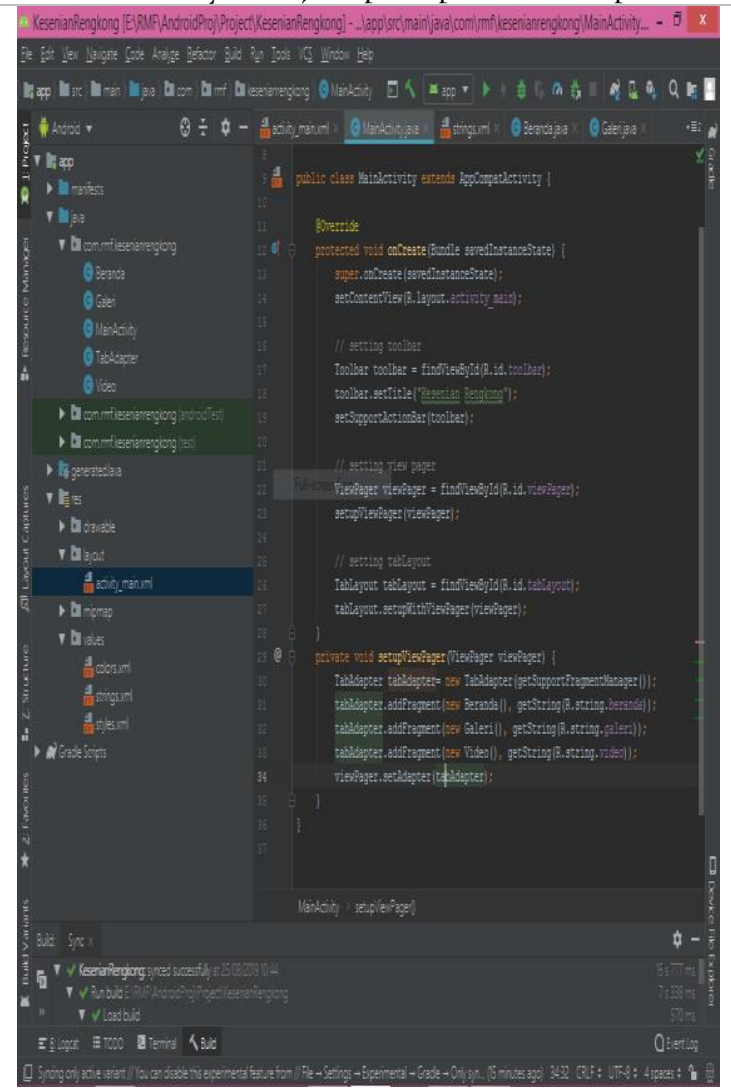

\section{Gambar 3. Gambar Tampilan} Kode Sumber Java

Setelah semua proses pembuatan aplikasi telah selesai dibuat maka lakukanlah proses testing yaitu menguji apakah aplikasi yang kita buat sudah sesuai rancangan yang telah dibuat sebelumnya dan bekerja dengan baik tanpa adanya kesalahan program. Gambar 5 menunjukkan tampilan ketika melakukan testing aplikasi.

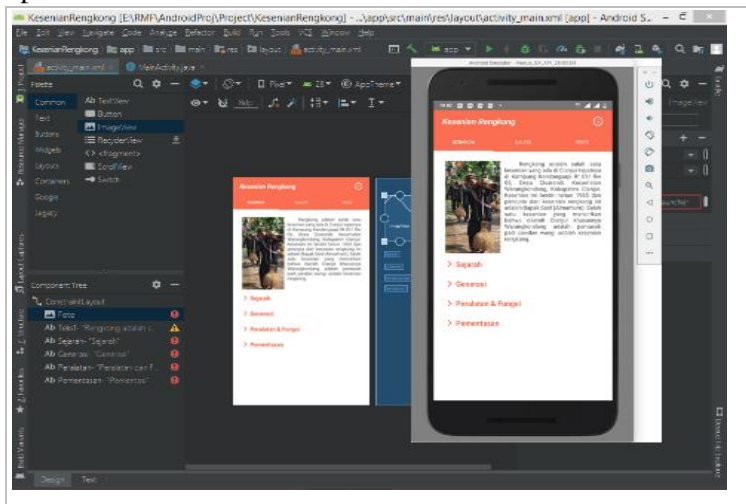

Gamber 4 tampilan testing

Proses terakhir dalam pembuatan aplikasi dengan menggunakan software Android Studio adalah deployment atau mempublish ke format .apk yang nantiya dapat diunduh melalui pasar aplikasi yaiatu Google Play Store dan dapat dijalankan di smartphone berbasis Android. Gambar 6 menunjukkan tampilan deployment generate ke format apk.

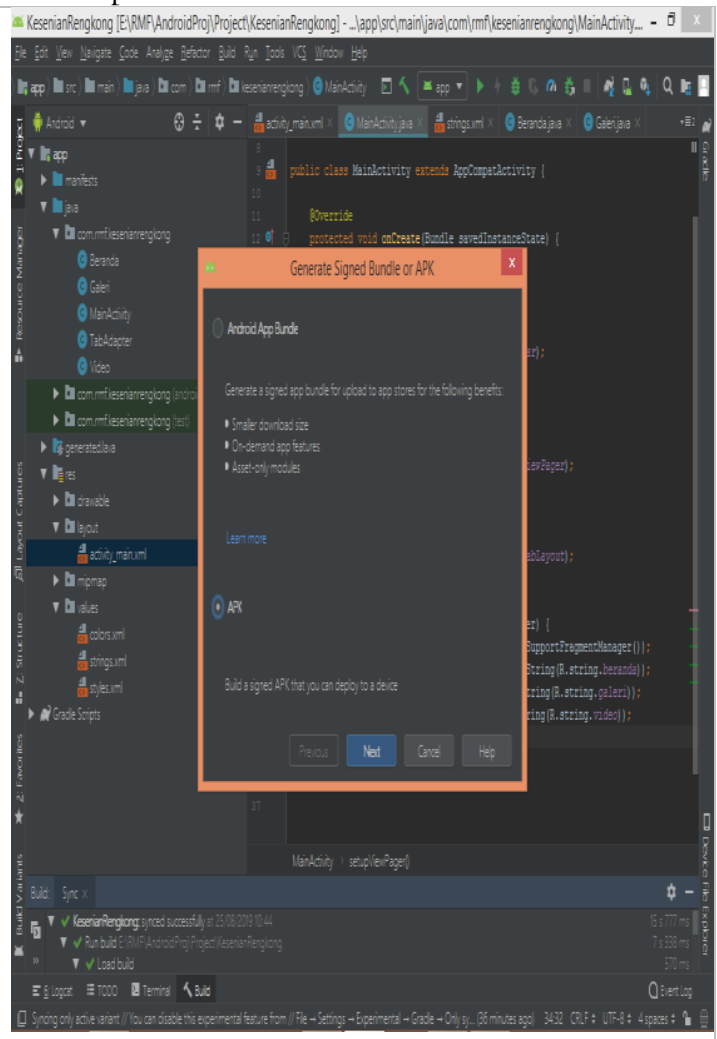

\section{Gambar 5. Gambar Tampilan Tahap Mempublish Apk}

Tahap pengujian pada smartphone dapat dijalankan dengan memindahkan berkas apk ke penyimpanan internal smartphone kemudian menginstalnya .apk tersebut. Pada penelitian ini tahap pengujian menggunakan smartphone Nokia 6 dengan spesifikasi CPU: Octa-core I.4 Ghz Qualcomm Snapdragon 430, Memory: 3 GB RAM, I6 GB Storage, Display: IPS LCD I6M colors Full HD (I080 x 1920) resolution, 5.5 inches display size, Main Camera: I6MP, f/2.0, OS: Android 9 Pie. Tahap pengujian dilakukan untuk mengetahui kinerja program yang telah dibuat. Apabila dalam tahap pengujian masih belum sesuai dan terdapat permasalahan, maka akan dilakukan perbaikan kembali terhadap aplikasi sebelum dilakukannya proses Validasi.

\section{Hasil Validasi Ahli}

Aplikasi Kesenian Rengkong telah divalidasi oleh ahli media pembelajaran, yaitu Aan Hasanah M.Pd. Instumen yang digunakan berupa angket yang berupa I 5 butir pertanyaan. Angket dalam penelitian 
ini menggunakan 4 pilihan jawaban yaitu : Sangat Baik (4), Baik (3), Cukup (2), dan Kurang (I).

Tabel I.

Hasil Validasi Ahli pada Aplikasi Kesenian Rengkong

\begin{tabular}{|c|c|c|c|c|c|c|c|c|}
\hline \multirow[b]{2}{*}{ No } & \multirow[b]{2}{*}{ Indikator } & \multicolumn{4}{|c|}{ Nilai } & \multirow[b]{2}{*}{$X$} & \multirow{2}{*}{$\begin{array}{l}X \\
i\end{array}$} & \multirow[b]{2}{*}{$\%$} \\
\hline & & $\begin{array}{l}S \\
B\end{array}$ & B & $\mathrm{C}$ & $\mathrm{K}$ & & & \\
\hline I. & $\begin{array}{l}\text { Keterbacaan teks atau } \\
\text { tulisan }\end{array}$ & & $\mathrm{X}$ & & & 3 & 4 & $\begin{array}{l}75 \\
\%\end{array}$ \\
\hline 2. & $\begin{array}{l}\text { Komposisi warna } \\
\text { teks dan background }\end{array}$ & & $\mathrm{X}$ & & & 3 & 4 & $\begin{array}{l}75 \\
\%\end{array}$ \\
\hline 3. & Pemilihan jenis huruf & & $\mathrm{X}$ & & & 3 & 4 & $\begin{array}{l}75 \\
\%\end{array}$ \\
\hline 4. & $\begin{array}{l}\text { Pemilihan ukuran } \\
\text { huruf }\end{array}$ & & $\mathrm{X}$ & & & 3 & 4 & $\begin{array}{l}75 \\
\%\end{array}$ \\
\hline 5. & $\begin{array}{l}\text { Kemudahan } \\
\text { berpindah menu } \\
\text { tampilan / navigasi }\end{array}$ & & $\mathrm{X}$ & & & 3 & 4 & $\begin{array}{l}75 \\
\%\end{array}$ \\
\hline 6. & Desain tampilan & & $\mathrm{X}$ & & & 3 & 4 & $\begin{array}{l}75 \\
\%\end{array}$ \\
\hline 7. & $\begin{array}{l}\text { Kualitas tampilan } \\
\text { gambar }\end{array}$ & & $\mathrm{X}$ & & & 3 & 4 & $\begin{array}{l}75 \\
\%\end{array}$ \\
\hline 8. & $\begin{array}{l}\text { Kualitas tampilan } \\
\text { video }\end{array}$ & & $\mathrm{X}$ & & & 3 & 4 & $\begin{array}{l}75 \\
\%\end{array}$ \\
\hline 9. & Konsistensi tombol & & $\mathrm{X}$ & & & 3 & 4 & $\begin{array}{l}75 \\
\%\end{array}$ \\
\hline IO. & $\begin{array}{l}\text { Kecepatan kinerja } \\
\text { aplikasi }\end{array}$ & & & $x$ & & 2 & 4 & $\begin{array}{l}50 \\
\% \\
\end{array}$ \\
\hline II. & Penggunaan bahasa & & $\mathrm{X}$ & & & 3 & 4 & $\begin{array}{l}75 \\
\%\end{array}$ \\
\hline $\mathrm{I} 2$. & $\begin{array}{l}\text { Kemudahan } \\
\text { penggunaan }\end{array}$ & & $\mathrm{X}$ & & & 3 & 4 & $\begin{array}{l}75 \\
\% \\
\end{array}$ \\
\hline I3. & $\begin{array}{l}\text { Kemudahan dalam } \\
\text { memahami } \\
\text { isi/materi }\end{array}$ & & $\mathrm{X}$ & & & 3 & 4 & $\begin{array}{l}75 \\
\%\end{array}$ \\
\hline $\mathrm{I} 4$. & $\begin{array}{lr}\text { Apakah } & \text { aplikasi } \\
\text { bermanfaat } & \text { bagi } \\
\text { pengguna? } & \end{array}$ & & $\mathrm{X}$ & & & 3 & 4 & $\begin{array}{l}75 \\
\%\end{array}$ \\
\hline I5. & $\begin{array}{l}\text { Kemudahan } \\
\text { penggunaan }\end{array}$ & & & $x$ & & 2 & 4 & $\begin{array}{l}50 \\
\%\end{array}$ \\
\hline & $X$ & & & & & $\begin{array}{l}4 \\
3\end{array}$ & & \\
\hline & $X i$ & & & & & & $\begin{array}{l}6 \\
0\end{array}$ & \\
\hline & $P$ & & & & & & & $\begin{array}{l}7 \mathrm{I} \\
.6 \\
7 \\
\%\end{array}$ \\
\hline
\end{tabular}

Berdasarkan tabel validasi ahli di atas, jumlah skor yang diperoleh adalah 43 dari skor ideal 60 . Dengan demikian $P$ (persentase data keseluruhan) adalah $71.67 \%$, sehingga pengembangan aplikasi kesenian rengkong dalam pembelajaran sastra berbasis kearifan lokal masuk dalam kategori cukup.

\section{Hasil Penerapan Aplikasi Kesenian Rengkong pada Pembelajaran Menulis Puisi}

Di bawah ini merupakan hasil angket pada pembelajaran menulis puisi dengan bantuan aplikasi Kesenian Rengkong pada 33 siswa X-TKJ-I SMK Negeri I Cianjur.
Tabel 2.

Rekapitulasi Jawaban Penggunaan Aplikasi Kesenian Rengkong dalam Pembelajaran Menulis Puisi

\begin{tabular}{|c|c|c|c|c|c|c|c|}
\hline $\begin{array}{l}\text { per } \\
\text { nya } \\
\text { taa } \\
\text { n }\end{array}$ & $\begin{array}{l}\text { Sela } \\
\text { lu }\end{array}$ & $\begin{array}{l}\text { Ser } \\
\text { ing }\end{array}$ & $\begin{array}{l}\text { Kada } \\
\text { ng- } \\
\text { kada } \\
\text { ng }\end{array}$ & $\begin{array}{l}\text { Tid } \\
\text { ak } \\
\text { Per } \\
\text { nah }\end{array}$ & $X$ & $X i$ & $\%$ \\
\hline $\mathrm{I}$ & IO & 8 & IO & 5 & 89 & I32 & $\begin{array}{l}67,42 \\
\%\end{array}$ \\
\hline 2 & I3 & I4 & 6 & 0 & 106 & I32 & $\begin{array}{l}80,30 \\
\%\end{array}$ \\
\hline 3 & 7 & 13 & I I & 2 & $9 \mathrm{I}$ & I32 & $\begin{array}{l}68,94 \\
\%\end{array}$ \\
\hline 4 & 9 & 20 & 2 & 2 & I02 & I32 & $\begin{array}{c}77,27 \\
\%\end{array}$ \\
\hline 5 & 8 & I0 & $\mathrm{I} 4$ & I & 91 & I32 & $\begin{array}{c}68,94 \\
\%\end{array}$ \\
\hline 6 & 7 & 12 & $\mathrm{I} 4$ & 0 & 92 & I32 & $\begin{array}{c}69,70 \\
\%\end{array}$ \\
\hline 7 & I9 & 4 & I0 & 0 & 108 & I32 & $\begin{array}{c}81,82 \\
\%\end{array}$ \\
\hline 8 & 16 & IO & 7 & 0 & I08 & I32 & $\begin{array}{c}81,82 \\
\%\end{array}$ \\
\hline 9 & 29 & 3 & I & 0 & 127 & I32 & $\begin{array}{c}96,2 \mathrm{I} \\
\%\end{array}$ \\
\hline IO & 6 & 2 & 7 & 18 & 62 & I32 & $\begin{array}{c}46,97 \\
\%\end{array}$ \\
\hline$X$ & $\mathrm{I} 24$ & 96 & 82 & 28 & 976 & & \\
\hline$X i$ & & & & & & $\begin{array}{c}\text { I32 } \\
0\end{array}$ & \\
\hline$P$ & & & & & & & $74 \%$ \\
\hline
\end{tabular}

Adapun penjabaran dari setiap pernyataan terhadap penggunaan aplikasi kesenian rengkong dalam pembelajaran sastra yakni sebagai berikut.

a) Dari 33 responden, sebanyak 10 responden atau (3I\%) siswa menyatakan "Selalu" atas pernyataan "Pembelajaran menulis puisi yang menggunakan aplikasi rengkong lebih menarik". Sebanyak 8 responden atau (24\%) siswa menyatakan "Sering", sebanyak I0 responden atau (30\%) siswa menyatakan "Kadangkadang”, dan sebanyak 5 responden atau (I5\%) siswa menyatakan "Tidak Pernah".

b) Dari 33 responden, sebanyak 13 responden atau (39\%) siswa menyatakan "Selalu" atas pernyataan "Aplikasi kesenian Rengkong mendorong saya dalam menemukan nilai-nilai kearifan lokal". Sebanyak I4 responden atau (43\%) siswa menyatakan "Sering", dan sebanyak 6 atau (I8\%) siswa menyatakan "Kadang-kadang".

c) Dari 33 responden, sebanyak 7 responden atau (21\%) siswa menyatakan "Selalu" atas pernyataan "Saya antusias dalam pembelajaran menulis puisi dengan menggunakan aplikasi kesenian rengkong". Sebanyak 13 responden atau (40\%) siswa menyatakan "Sering", sebanyak II responden atau (33\%) siswa menyatakan "Kadang-kadang", dan sebanyak 2 responden atau (6\%) siswa menyatakan "Tidak Pernah”. 
d) Dari 33 responden, sebanyak 9 responden atau (27\%) siswa menyatakan "Selalu" atas pernyataan "Pembelajaran menulis puisi yang menggunakan aplikasi kesenian Regkong dapat menumbuhkan karakter siswa”. Sebanyak 20 responden atau (6I\%) siswa menyatakan "Sering", sebanyak 2 responden atau (6\%) siswa menyatakan "Kadang-kadang", dan sebanyak 2 responden atau (6\%) siswa menyatakan "Tidak Pernah".

e) Dari 33 responden, sebanyak 8 responden atau (24\%) siswa menyatakan "Selalu" atas pernyataan "Saya mampu membuat sebuah puisi dengan melihat aplikasi Rengkong". Sebanyak I0 responden atau (30\%) siswa menyatakan "Sering", sebanyak I4 responden atau (43\%) siswa menyatakan "Kadangkadang”, dan sebanyak I responden atau (3\%) siswa menyatakan "Tidak Pernah".

f) Dari 33 responden, sebanyak 7 responden atau (21\%) siswa menyatakan "Selalu" atas pernyataan "Pembelajaran menulis puisi menggunakan apliasi kesenian Rengkong membuat daya lebih aktif dalam belajar". Sebanyak 12 responden atau (36\%) siswa menyatakan "Sering", dan sebanyak I4 responden atau (43\%) siswa menyatakan "Kadang-kadang".

g) Dari 33 responden, sebanyak I9 responden atau (58\%) siswa menyatakan "Selalu" atas pernyataan "Pembelajaran menulis puisi menggunakan aplikasi Rengkong membuat saya bosan di kelas". Sebanyak 4 responden atau ( $12 \%)$ siswa menyatakan "Sering", dan sebanyak IO responden atau (30\%) siswa menyatakan "Kadang-kadang".

h) Dari 33 responden, sebanyak I6 responden atau (49\%) siswa menyatakan "Selalu" atas pernyataan "Pembelajaran menulis puisi menggunakan aplikasi Rengkong membuat materi lebih diingat”. Sebanyak I0 responden atau $(30 \%)$ siswa siswa menyatakan "Sering", dan sebanyak 7 responden atau (21\%) siswa menyatakan "Kadang-kadang".

i) Dari 33 responden, sebanyak 29 responden atau $(88 \%)$ siswa "menyatakan "Selalu" atas pernyataan "Pembelajaran menulis puisi menggunakan aplikasi kesenian Rengkong membuang-buang waktu belajar saya”. Sebanyak 3 responden atau (9\%) siswa menyatakan "Sering", dan sebanyak I responden atau (3\%) siswa menyatakan "Kadang-kadang".

j) Dari 33 responden, sebanyak 6 responden atau (I8\%) siswa menyatakan "Selalu" atas pernyataan "Aplikasi Rengkong kurang bermanfaat dalam pembelajaran menulis puisi”. Sebanyak 2 responden atau (6\%) siswa menyatakan "Sering", sebanyak 7 responden atau (2I\%) siswa menyatakan "Kadangkadang", dan sebanyak I8 responden atau (55\%) siswa menyatakan "Tidak Pernah".

Berdasarkan hasil rekapitulasi di atas, jumlah skor adalah 976 dari skor ideal 1320. Dengan demikian $P$ (persentase data keseluruhan) adalah $74 \%$, sehingga penggunaan aplikasi kesenian rengkong dalam pembelajaran sastra berbasis kearifan lokal tersebut dapat digunakan dalam pembelajaran karena sudah masuk dalam kategori cukup.

\section{Nilai Karakter pada Puisi Siswa}

Berdasarkan hasil penerapan aplikasi Kesenian Rengkong pada pembelajaran menulis puisi, didapatkan lima nilai menghargai prestasi, dua nilai cinta tanah air, empat belas nilai religius, enam nilai jujur, tiga nilai kerja keras, enam nilai tanggung jawab, empat nilai toleransi, dan tujuh nilai kreatif.

\section{Simpulan}

Pengembangan produk aplikasi berbasis mobile dibuat dengan menggunakan software Android Studio. Proses pembuatan aplikasi diakhiri dengan melakukan proses testing untuk menguji aplikasi yang telah dibuat. Pengembangan produk aplikasi berbasis mobile akan dipublish ke format .apk yang dapat diunduh melalui aplikasi yaitu Google Play Store dan dapat dijalankan di smartphone berbasis Android. Tahap pengujian dapat dijalankan dengan memindahkan berkas .apk ke penyimpanan internal smartphone kemudian menginstalnya .apk tersebut.

Berdasarkan hasil validasi ahli pengembangan aplikasi Kesenian rengkong dalam pembelajaran sastra berbasis kearifan lokal masuk dalam kategori cukup untuk dijadikan bahan pembelajaran.

Sedangkan berdasarkan hasil angket penerapan pembelajaran menulis puisi pada siswa SMK Negeri I Cianjur dengan jumlah responden 33 orang diperoleh presentase sebanyak 74\%. Artinya penggunaan aplikasi Kesenian Rengkong dalam pembelajaran sastra berbasis kearifan lokal tersebut dapat digunakan dalam pembelajaran karena sudah masuk dalam kategori cukup. Setelah penerapan aplikasi, ditemukan delapan nilai karakter pada puisi siswa, diantaranya nilai menghargai prestasi, cinta tanah air, religius, jujur, kerja keras, tanggung jawab, toleransi, dan kreatif.

\section{Persantunan}

Artikel ini dapat diselesaikan dengan baik atas dukungan moriil dan materiel dari beberapa pihak. Penulis mengucapkan terima kasih kepada Direktorat Riset dan Pengabdian Masyarakat - Direktorat Jenderal Penguatan Riset dan Pengembangan - 
Kementerian Riset, Teknologi, dan Pendidikan Tinggi RI, yang mendanai penelitian, juga pihak lainnya seperti Fakultas, prodi, narasumber, dan rekan-rekan yang memberikan motivasi.

\section{Daftar Pustaka}

Adawiyah, A., \& Munsi, F. (2018). Mengeksplorasi Nilai-nilai Budaya Tembang Sunda Cianjuran (Exploring the Cultural Values Tembang Sunda Cianjuran). Jurnal Bahasa, Sastra dan Pembelajarannya, 8(I), I32-I43.

Bakti, S., Hasibuan, N. A., Sianturi, L. T., \& Sianturi, R. D. (2016). Perancangan Aplikasi Pembelajaran Coreldraw X3. 3(4), 32-35.

Danial, E., \& Prayogi, R. (2016). Pergeseran Nilainilai Budaya Pada Suku Bonai Sebagai Civic Culture di Kecamatan Bonai Darussalam Kabupaten Rokan Hulu Provinsi Riau. Humanika, 23(I).

Davison, G. and M. C. (I99I). A Heritage Handbook. NSW Allen\&Unwin.

Fajarini, U. (20I4). Peranan kearifan lokal dalam pendidikan karakter. Sosio Didaktika, I(2). Https://docobook.com/peranan-kearifanlokal-dalam-pendidikan-karakter.html.

Hamalik, U. (2005). Psikologi Belajar dan Mengajar. Bandung: Sinar Baru.

Haryadi. (2006). Pengembangan Media Pembelajaran Kimia berbantu Komputer Tentang Kimia Unsur untuk Siswa Kelas XII. Yogyakarya: UNY.

Karmadi, A. D. (2007). Budaya Lokal sebagai Warisan Budaya dan Pelestariannya. Semarang:
Dinas Pendidikan dan Kebudayaan Propinsi Jawa Tengah.

Ningsih, D. N., Adawiyah, A., \& Munsi, M. F. (2019). Character Value Internalization in Learning to Poem. Seminar Nasional Pendidikan, 40-46. Https://jurnal.umj.ac.id/index.php/SEMNA SFIP/index.

Ningsih, D. N., \& Erdlanda, F. M. C. (2018). Nilai Pendidikan dalam Kesenian Rengkong di Cianjur Jawa Barat: Kajian Etnopedagogi. Bina Edukasi, II(I), I-I2.

Rabiah, S. (2018). Penanaman Nilai Karakter melalui Pembeajaran Sastra dalam Mata Kuliah Bahasa Indonesia di Perguruan Tinggi. Pertemuan Ilmiah Bahasa dan Sastra Indonesia XXXVI, II I. Https://doi.org/I0.3I227/osf.io/ktv9w.

Setiadi, A., Yuliatmojo, P., \& Nurhidayat, D. (2018). Pengembangan Aplikasi Android untuk Pembelajaran Pneumatik. Jurnal Pendidikan Vokasional Teknik Elektronika, I(I), I-5.

Setyowati, E. (2009). Pendidikan budi pekerti menjadi mata pelajaran di sekolah. Journal of Education Research, 38(2), I48-I54. Https://journal.unnes.ac.id/nju/index.php/L $\mathrm{IK} /$ article/view/487/444.

Sugiyono. (2010). Metode Penelitian Pendidikan (Pendekatan Kualitatif, Kuantitatif, dan R\&D). Bandung: Alfabeta.

Syamsiah. (2017). Pengembangan Aplikasi Multimedia Pembelajaran Interaktif untuk Mata Pelajaran Bahasa Indonesia. SAP, 2. 